Acta Regionalia et Environmentalica 2

Nitra, Slovaca Universitas Agriculturae Nitriae, 2016, pp. 27-30

\title{
CHANGE IN THE CONTENT OF MOBILE FORMS OF Cu AND Zn IN THE LEACHED CHERNOZEM UNDER THE PYROGENIC EFFECT
}

\author{
T.A. DEVYATOVA*, Yu.S. GORBUNOVA, N.A. SOROKINA, L.A. YABLONSKIKH \\ Voronezh State University, Voronezh, Russia
}

\begin{abstract}
The forest fire effect on the leached chernozem results in the organic matter loss and the decrease in content of alkali-hydrolysed nitrogen compounds. The content of ash components as well as mobile forms of $\mathrm{Cu}$ and $\mathrm{Zn}$ in the topsoil has increased. It can be connected with the ashes appearing in the soil surface, which are rich in microelements.
\end{abstract}

Keywords: leached chernozem, heavy metals, forest fire, mixed forest, broadleaf forest

The research was carried out on the territory of the Central Chernozem region in the southern part of the Lipetsk region. The middle latitudes and a significant remoteness from seas and oceans define a temperate continental climate of the region studied. The research territory can be characterized by a relative deficit of atmospheric moistening and its irregularity (Climate Resources of Central Chernozem) The Zadonsk district of the Lipetsk region is located in the Central Russian Upland with the predominance of valley gully as well as ravine landforms (Milkov, 1994)

Transformation of soils after fires has been studied by a number of authors (Karpachevsky et al. 1996; Tarasov, 2011; Shapchenkova, 2011). Yet it was pointed out that forest fires result in the significant change in physical and chemical properties, granulometric composition, water and air as well as hydrometric regimes of soils. Besides, there is a change in quantity and stability of the organic matter. Genesis peculiarities of chernozems explain their high resistance to heavy metals (HM) contamination. Basic typomorphic properties of chernozems (large humus reserves, high capacity of soil absorption complex, oxidation conditions, and neutral reaction of medium) affect the transformation of HM into immobile forms and forms which are non-toxic for living organisms (Devyatova, 2006). There is very little data on the change in the content of mobile forms of HM. Detection of regularities concerning mobile forms of $\mathrm{Cu}$ and $\mathrm{Zn}$ in pyrogenic leached chernozems is therefore one of the most topical issues which deal with the current biogeocoenosis state.

The objective of the paper is to define quality and quantity changes in chemical composition of the leached chernozem after the forest fire.

The goals of our research were the following: investigation of soil profiles and description of their characteristics, detection of the basic chemical characteristics of the soils investigated (Vorobyova, 1998), detection of the content of the HM compounds (www.Lumex.ru), variational and statistical processing of the results using programmes such as Stadia and Microsoft Excel as well as the comparative analysis of the results.

\section{Material and methods}

The object of the research is the medium-humic, loamy leached chernozem with the humus layer of medium thickness on the topsoil carbonate loam. It is located at the territory of the Zadonsk district, Lipetsk region near Kashary village. Mesorelief is presented by a watershed plateau whereas microrelief is characterized by soil chemical composition changes around tree trunks. The baseline areas were the identical leached chernozems in pine and deciduous forests which are located $1.5 \mathrm{~km}$ from the area destroyed by fire. Baseline soils mean the soils which are identical in structure and properties to the studied ones, but which were not affected by forest fires.

Soil samples selection was carried out in 2011 at the territory where pyrogenic effect occurred in 2010. 9 test pits were made in mixed forest, and another 9 test pits were made in a broadleaf forest (with three replications). The samples were taken out of test pits layer by layer until the depth of $40-50 \mathrm{~cm}$ ( 270 soil samples).

Besides, 2 longitudinal sections showing soil-like rock were made in baseline areas without any pyrogenic effect. Soil sample selection was carried out layer by layer (0-10, 10-20, 20-30... 140-150 cm) in accordance with GOST (with three replications) (www.ekoekspert.ru). 90 samples were taken at the baseline area.

Basic chemical characteristics of these soil samples were defined according to the following general methods: total humic matter by the Tiurin method in the modification of Simakov; nitrogen of easily hydrolyzed compounds in the alkali extract by the Kornfield method; photocolorimetric determination of easily soluble phosphates by the Chrikov method, in carbonate samples - by the Machigin method; exhangeable potassium in non-carbonate soils by the

Contact address: T.A. Devyatova, Voronezh State University, Voronezh, Russia, e-mail: e-mail: devyatova@bio.vsu.ru 
Chirikov method with flame photometric determination, in carbonate samples - by the Protasov method (Vorobyova, 1998). The detection of HM was carried out with the use of atomic absorption spectrometer "MGA-915" in the accredited laboratory meets all the requirements of GOST R ISO/MEK 17025-2006 PND F 16.1:2:2.2.63-09 "Methods of measurements of mass fraction of mobile forms of metals (zinc, copper, nickel, manganese, lead, cadmium, chromium, iron, aluminium, titanium, cobalt, arsenic, vanadium) in soils, waste, composts, sewage sludge applying the atomic emission method with the atomization in inductively couple argon plasma" (www. lumex.ru). Stadia and Microsoft Excel programmes were used to carry out variational and statistical processing of the data received.

\section{Results and discussion}

The most important ecological effect from fires is presented by ecosystem organic matter losses, including soil organic matter losses. There is a tendency of the decrease in humus content at $0-10 \mathrm{~cm}$ depth detected in the studied pyrogenic soils. Maximum losses in the leached chernozem were found in mixed forest and make $27.1 \%$ (the humus content in the baseline area is $6.08 \%$ whereas on the territory affected by fire it is $4.43 \%$ ). The humus content in pyrogenic soils in the leached chernozem located in the broadleaf forest has decreased on $23.1 \%$ (the initial humus content was $6.40 \%$ and after the fire effect it became $4.92 \%$ ) (Table 1, 2) (Gorbunova, 2013, Gorbunova, 2013, Devyatova, 2014, Gorbunova, 2014, Belik, 2016). We found out that the processes of humus losses are especially active during forest litter and humus topsoil burning. It is connected with the

Table 1 Chemical characteristics of leached chernozem (baseline soil)

\begin{tabular}{|c|c|c|c|c|c|c|c|c|}
\hline \multirow[t]{3}{*}{ Depth in cm } & \multicolumn{4}{|c|}{ Mixed forest } & \multicolumn{4}{|c|}{ Broadleaf forest } \\
\hline & \multirow{2}{*}{ humus in $\%$} & nalk. - hydr. & $\mathrm{P}_{2} \mathrm{O}_{5}$ & $\mathrm{~K}_{2} \mathrm{O}$ & \multirow{2}{*}{ humus in $\%$} & nalk. - hydr. & $\mathrm{P}_{2} \mathrm{O}_{5}$ & $\mathrm{~K}_{2} \mathrm{O}$ \\
\hline & & \multicolumn{3}{|c|}{$\mathrm{mg} 100 \mathrm{~g}^{-1}$ of soil } & & \multicolumn{3}{|c|}{$\mathrm{mg} 100 \mathrm{~g}^{-1}$ of soil } \\
\hline $0-10$ & 6.08 & 24.1 & 7.78 & 18.5 & 6.40 & 25.40 & 8.56 & 18.7 \\
\hline $10-20$ & 5.24 & 21.50 & 7.23 & 18.20 & 5.54 & 22.70 & 7.83 & 18.3 \\
\hline $20-30$ & 3.97 & 17.20 & 6.69 & 17.50 & 4.13 & 17.40 & 7.19 & 17.5 \\
\hline $30-40$ & 3.37 & 11.40 & 5.85 & 16.90 & 3.46 & 11.50 & 6.48 & 16.8 \\
\hline $50-60$ & 2.89 & 8.48 & 5.53 & 15.70 & 2.91 & 8.49 & 5.92 & 15.7 \\
\hline $70-80$ & 1.62 & 1.60 & 5.31 & 14.00 & 1.63 & 1.63 & 5.30 & 14.1 \\
\hline 90-100 & 0.54 & - & 5.29 & 13.40 & 0.52 & - & 5.29 & 13.5 \\
\hline $110-120$ & 0.49 & - & 5.23 & 12.70 & 0.48 & - & 5.24 & 12.7 \\
\hline $140-150$ & 0.26 & - & 5.22 & 10.80 & 0.25 & - & 5.22 & 10.8 \\
\hline
\end{tabular}

Table 2 Statistical results of pyrogenic soils chemical characteristics

\begin{tabular}{|c|c|c|c|c|c|}
\hline \multirow[t]{2}{*}{ Depth in $\mathrm{cm}$} & \multirow[t]{2}{*}{$n$} & \multirow[t]{2}{*}{ Humus in \% } & Nalk. - hydr. & $\mathrm{P}_{2} \mathrm{O}_{5}$ & $\mathrm{~K}_{2} \mathrm{O}$ \\
\hline & & & \multicolumn{3}{|c|}{$\mathrm{mg} 100 \mathrm{~g}^{-1}$ of soil } \\
\hline \multicolumn{6}{|c|}{ medium-humic, loamy leached chernozem with the humus layer of medium thickness (mixed forest) } \\
\hline 0-10 & 9 & $4.43 \pm 0.56$ & $18.2 \pm 0.89$ & $8.72 \pm 0.58$ & $19.2 \pm 1.41$ \\
\hline 10-20 & 9 & $4.98 \pm 0.49$ & $20.8 \pm 0.71$ & $6.94 \pm 0.57$ & $18.8 \pm 1.29$ \\
\hline 20-30 & 9 & $3.82 \pm 0.44$ & $16.6 \pm 0.64$ & $6.74 \pm 0.49$ & $18.0 \pm 1.08$ \\
\hline 30-40 & 9 & $3.34 \pm 0.39$ & $11.3 \pm 0.55$ & $5.89 \pm 0.51$ & $17.1 \pm 0.91$ \\
\hline 40-50 & 9 & $2.93 \pm 0.28$ & $9.35 \pm 0.68$ & $5.71 \pm 0.46$ & \\
\hline \multicolumn{6}{|c|}{ medium-humic, loamy leached chernozem with the humus layer of medium thickness (broadleaf forest) } \\
\hline 0-10 & 9 & $4.92 \pm 0.49$ & $18.6 \pm 0.82$ & $9.54 \pm 0.57$ & $19.5 \pm 1.67$ \\
\hline $10-20$ & 9 & $5.40 \pm 0.51$ & $19.9 \pm 0.75$ & $8.17 \pm 0.49$ & $18.5 \pm 1.51$ \\
\hline $20-30$ & 9 & $4.09 \pm 0.37$ & $16.5 \pm 0.58$ & $7.30 \pm 0.45$ & $17.4 \pm 0.98$ \\
\hline $30-40$ & 9 & $3.42 \pm 0.42$ & $10.5 \pm 0.79$ & $6.48 \pm 0.48$ & $16.6 \pm 0.93$ \\
\hline 40-50 & 9 & $3.07 \pm 0.25$ & $10.1 \pm 0.54$ & $6.40 \pm 0.46$ & $15.7 \pm 1.12$ \\
\hline
\end{tabular}

$\mathrm{n}$ - number of samples, $\mathrm{x}$ - arithmetic mean, - arithmetic mean with arithmetic mean error 


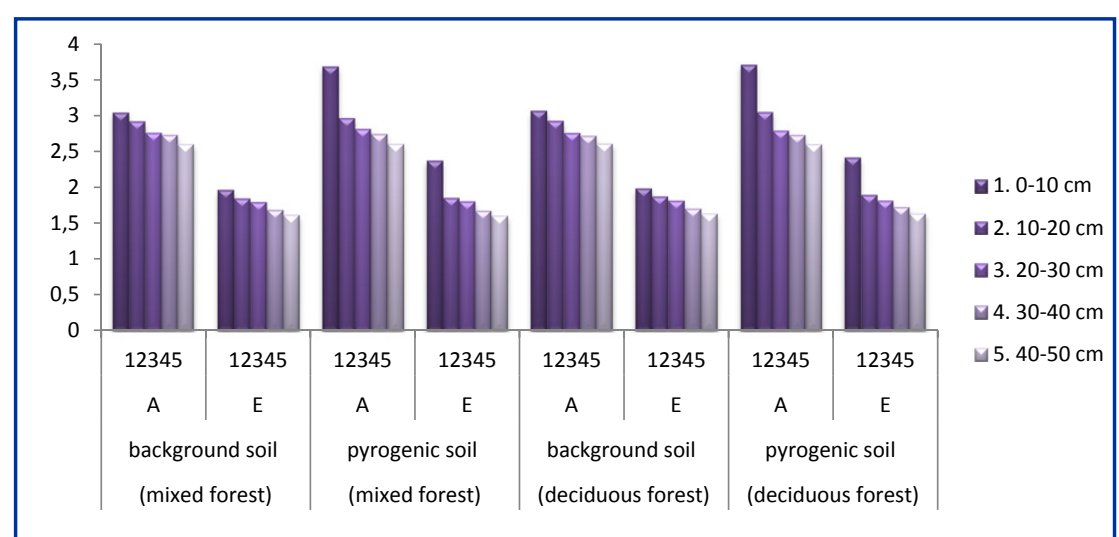

Figure 1 Mobile forms of Cu content in $\mathrm{mg} \mathrm{kg}^{-1}$

A - acid-soluble, E - exchangeable in the leached chernozem (baseline and pyrogenic areas)

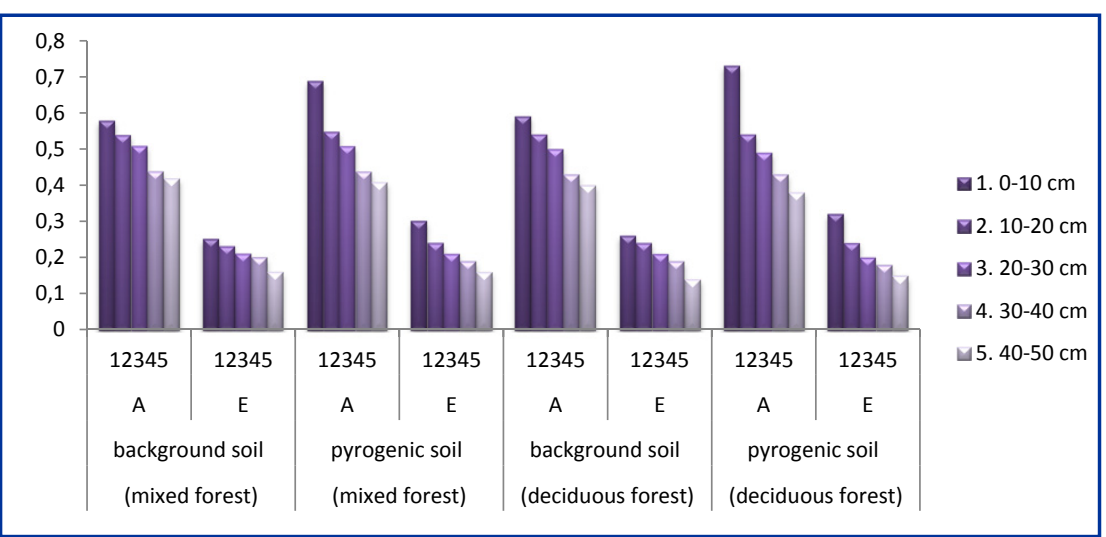

Figure 2 Mobile forms of Zn content in $\mathrm{mg} \mathrm{kg}^{-1}$

A - acid-soluble, E - exchangeable in the leached chernozem (baseline and pyrogenic areas)

direct organic matter disruption under high temperatures (humus burning).

The alkali-hydrolyzed nitrogen content in the leached chernozem after the forest fire in mixed forest in the layer of $0-1 \mathrm{~cm}$ has decreased on $24.5 \%$ comparing to the baseline soils (from $24.1 \mathrm{mg} 100 \mathrm{~g}^{-1}$ of soil up

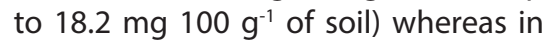
the birch forest it has decreased on $26.8 \%$ (from $25.4 \mathrm{mg} 100 \mathrm{~g}^{-1}$ of soil up to $18.6 \mathrm{mg} 100 \mathrm{~g}^{-1}$ of soil) due to the nitrogen organic matter burning under high temperatures (Table 1, 2) (Gorbunova, 2013).

$\mathrm{P}_{2} \mathrm{O}_{5}$ content in the leached chernozem in mixed forest in the layer of $0-10 \mathrm{~cm}$ after the forest fire has increased by $12.1 \%$ comparing to the baseline soils (from $7.78 \mathrm{mg} 100 \mathrm{~g}^{-1}$ of soil up to $8.72 \mathrm{mg} / 100 \mathrm{~g}$ of soil). The pyrogenic effect in the leached chernozem located in the broadleaf forest in the layer of $0-10 \mathrm{~cm}$ resulted in the increase of $\mathrm{P}_{2} \mathrm{O}_{5}$ content by $11.4 \%$ (from $8.56 \mathrm{mg}^{100 \mathrm{~g}^{-1} \text { of soil up }}$ to $9.54 \mathrm{mg} 100 \mathrm{~g}^{-1}$ of soil) (table 1, 2) content with their increase up to $3.69 \mathrm{mg} \mathrm{kg}^{-1}$ in the mixed forest and $3.71 \mathrm{mg} \mathrm{kg}^{-1}$ in the broadleaf forest comparing to the baseline values for the mixed forest $-3.04 \mathrm{mg} \mathrm{kg}^{-1}$, for the broadleaf forest $-3.07 \mathrm{mg} \mathrm{kg}^{-1}$ (Figure 1). Cu exchangeable and acid soluble compounds content decreased with the depth due to the alkalizing of the soil solution (Figure 1). Mobile forms of Cu content in the layer of $0-10 \mathrm{~cm}$ after the pyrogenic effect did not exceed the maximum residue level $(\mathrm{MRL})=30-40$ $\mathrm{mg} \mathrm{kg}^{-1}$. Thus, forest fire did not cause the soil contamination with HM.

Exchangeable forms of $\mathrm{Zn}$ content in the upper $0-10 \mathrm{~cm}$ layer of the leached chernozem changed significantly both in the mixed forest and in the broadleaf forest. It varies from $0.25-0.26 \mathrm{mg} \mathrm{kg}^{-1}$ for the baseline soils up to $0.30-0.32 \mathrm{mg} \mathrm{kg}^{-1}$ for the pyrogenic soils (Gorbunova, 2013). The same tendency was marked for the $\mathrm{Zn}$ acid soluble compounds. The content varied within the limits of $0.58-0.59 \mathrm{mg} \mathrm{kg}^{-1}$ for the baseline soils of mixed forest and broadleaf forest and correspondingly $0.69-0.73 \mathrm{mg} \mathrm{kg}^{-1}$ for the pyrogenic soils (Figure 2). There was a gradual decrease in the quantity of exchangeable and acid soluble $\mathrm{Zn}$ down the leached chernozems profile (Figure 2). The data received about the mobile forms of $\mathrm{Zn}$ in the leached chernozems indicates that there was no soil contamination with HM, because the element quantity did not exceed the MRL value $=23 \mathrm{mg} \mathrm{kg}^{-1}$.

\section{Conclusion}

m $100 \mathrm{~g}^{-1}$ of soil up to $19.2 \mathrm{mg}$ $100 \mathrm{~g}^{-1}$ of soil) whereas in the broadleaf forest $\mathrm{K}_{2} \mathrm{O}$ content has increased by

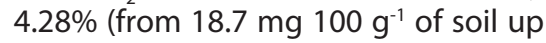

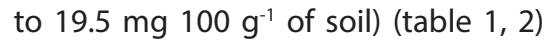
(Gorbunova, 2013). Increase in $\mathrm{P}_{2} \mathrm{O}_{5}$ and $\mathrm{K}_{2} \mathrm{O}$ concentration in pyrogenic soils was due to their larger content in the ashes appeared after the forest fire.

The content of $\mathrm{Cu}$ exchangeable compounds in the layer of $0-10 \mathrm{~cm}$ changed insignificantly in the baseline leached chernozems of various biotopes from $1.96 \mathrm{mg} \mathrm{kg}^{-1}$ in the mixed forest up to $1.98 \mathrm{mg} \mathrm{kg}^{-1}$ in the broadleaf forest whereas in pyrogenic soils - from $2.37 \mathrm{mg} \mathrm{kg}^{-1}$ in the mixed forest up to $2.41 \mathrm{mg} \mathrm{kg}^{-1}$ in the broadleaf forest (Figure 1) (Gorbunova, 2013). Pyrogenic effect in the layer of $0-10 \mathrm{~cm}$ also resulted in the change in acid soluble compounds
The results of the research conducted show that there are organic matter losses in topsoil of pyrogenic soils, which is connected with the direct organic matter disruption under high temperatures (humus burning). Humus losses were mostly visible in the layer of $0-10 \mathrm{~cm}$, where the transformation of mineral substances connected with the organic matter in soluble forms happened. Alkalihydrolyzed nitrogen content in all the pyrogenic soils studied decreases comparing to the baseline soils. This is because most of nitrogen organic compounds burn out under the temperature of about $500{ }^{\circ} \mathrm{C}$. The pyrogenic effect resulted in the increase of $\mathrm{P}_{2} \mathrm{O}_{5}$ and $\mathrm{K}_{2} \mathrm{O}$ ash components content in the upper 
0-10 cm layer due to their large content in the ashes appeared after the forest fire.

Mobile forms of $\mathrm{Cu}$ and $\mathrm{Zn}$ appearing in the leached chernozem surface with the ashes after the forest fire were connected with the soil organic matter. Increase in mobile forms of $\mathrm{Zn}$ and $\mathrm{Cu}$ content in the pyrogenic soils were within the MRL, and forest fire was not the cause of soil contamination with HM. Low level of mobility, which is typical for $\mathrm{Zn}$ compounds, makes this element hardly available for plant feeding. Thus, the increase in the exchangeable $\mathrm{Zn}$ content in the leached chernozems studied had a positive effect on the supply of nutrients for plants. To sum up, the increase in the exchangeable forms of $\mathrm{Zn}$ and $\mathrm{Cu}$ in the leached chernozem after the forest fire can be seen as the use of micronutrient fertilizer for the soil in relation to plants.

The data received on chemical characteristics as well as on mobile forms of HM in the studied soils can be used for the creation and functioning of geoinformation systems, for the arrangement of soil and ecology monitoring as well as for the assessment of the studied soils degradation level after the pyrogenic effect. The new evidence and theory received are used in General Ecology lecture course and in Industrial Systems and Ecological Risks optional course delivered at the Ecology and Land Resources department of the Voronezh State University for students majoring in ecology and nature management.

\section{References}

BELIK, A.V. - DEVYATOVA, T.A. - BOZHKO, S.N. - GORBUNOVA, YU. S. 2016. The Infield Varietu of Available Forms in the Forest-steppe of Western Part Central Chernozemic Region. In. Geophysical Research Abstracts, vol. 18, 2016, p. 7190.

CLIMATE RESOURCES of Central Chernozem, Bryansk and Orel Regions. 1978. Leningrad : Gidrometeoizdat, 1978. pp. 5-9.

DEVYATOVA, T.A. 2006. Anthropogenic dynamics and biodiagnostics of ecological state of chernozems of the Central Chernozem Region : dissertation ... of Doctor of Biology : 03.00.27, 03.00.16. 2006. 403 p.

DEVYATOVA, T.A. - GORBUNOVA, YU.S. - GRIGORJEVSKAYA, A.Ya 2014. Modern evolution of soils and flora of the Russian Plain forest- steppe after forest fires: monograph. Voronezh : Nauchnaya Kniga, 2014. 259 pp.

GORBUNOVA, YU.S. - DEVYATOVA, T.A. 2013. Change of leached chernozem agrochemical properties in case of forest fire. In Agrochemical Herald, 2013, no. 3, pp. 45-46.

GORBUNOVA, YU.S. - DEVYATOVA, T.A. - GRIGORJEVSKAYA, A.Ya. 2014. Influence fire on the soil and vegetable cover of the woods of the Central Chernozem region of Russia. In Aridnye Ekosistemy, vol. 20, 2014, no. 4 (61), pp. 92-103.

GORBUNOVA, YU.S. - DEVYATOVA, T.A. 2013. The changes chemical composition of chernozem leaching under pirogenic influence. Proceedings of VSU, Series: Chemistry. In Biology. Pharmacy, 2013, no. 1, pp. 9-14

GOST 17.4.4.02-84 Environmental protection. Soil. Methods for sampling and preparation of soil for chemical, bacteriological and helminthological analysis. Electronic resource: http: //www. ecoekspert.ru/art/JV2orm/54.html

KARPACHEVSKY, L.O. - Rozhkov, V.A. - Karpachevsky, M.L. Shvidenko, A.Z. 1996. Forest, soil and forest pedology. In Pedology, 1996, no. 5, pp. 587-598.

MILKOV, F.N. - MIKHNO, V.B. - POROSENKOV, YU.V. 1994. Georgrapgy of Voronezh Region. Voronezh : Voronezh State University, 1994, $130 \mathrm{p}$.

PND F 16.1:2:2.2.63-09. Methods of measurements of mass fraction of mobile forms of metals (zinc, copper, nickel, manganese, lead, cadmium, chromium, iron, aluminium, titanium, cobalt, arsenic, vanadium) in soils, waste, composts, sewage sludge applying the atomic emission method with the atomization in inductively couple argon plasma. Electronic resource: http: // www.lumex.ru/ metodics/09AR01.05.29-1.pdf

SHAPCHENKOVA, O.A. - KRASNOSHCHEKOV, YU.N. - LOSKUTOV S.R. 2011. Application of the methods of thermal analysis for the assessment of organic matter in postpyrogenic soils. In Pedology, 2011, no. 6, pp. 738-747.

TARASOV, P.A. - IVANOV, V.A. - IVANOVA, G.A. KRASNOSHCHEKOVA, E.N. 2011. Post-pyrogenic changes in the hydrothermal parameters of soils in middle-taiga pine forests. In Pedology, 2011, no. 7, pp. 795-803.

VOROBYOVA, L.A. 1998. Soil chemical analysis. Moscow : MSU, $1998,272 \mathrm{p}$. 